\title{
Quality Assessment of Sandcrete Blocks Produced in Kano Municipal Local Government, Kano State, Nigeria
}

\author{
Govind Singh Chauhan, Mahmoud Murtala Farouk, Auwal Alhassan Musa, Lasmar Garba
}

\begin{abstract}
This research entails the assessment of sandcrete blocks quality produced in Kano municipal Local govt. Kano state of Nigeria. six sandcrete blocks were selected from eight commercial block industries from the study area, the result obtained shows that the aggregates used satisfied the overall grading requirement specified in $B S$ 882, 1992.The mix ratio adopted by the industries ranges from 1:12 to $1: 14$ which is against the standard of 1:6 specified in NIS 87:2004. water absorption was from $14.67 \%$ to $18.10 \%$ which reveals that all samples were above the maximum specified $12 \%$ as stated by the (NIS). The result of compressive strength of blocks tested ranges $0.2869 \mathrm{~N} / \mathrm{mm}^{2}$ to $0.4884 \mathrm{~N} / \mathrm{mm}^{2}$, its average for the eight factories selected was $0.432 \mathrm{~N} / \mathrm{mm}^{2}$. Which reveals that all samples were below the maximum specified value of $2.8 \mathrm{~N} / \mathrm{mm}^{2}$, as stated by (NIS 87: 2000). In compliances with the provisions prescribed by the codes/agencies. the manufacturers were recommended to improve on their mixing process, material selection and curing processes in order to produce sandcrete blocks of high quality to conform with the standard.
\end{abstract} Standard

Keywords: Assessment, Commercial, Water Absorption,

\section{INTRODUCTION}

in recent years the construction industry and construction practitioners had gone through a lot of arguments and criticisms on issue of building collapse in the country. buildings are constructed primarily to meet the physical need of shelter. shelter is the third human need after food and water. it offers an appreciable protection for man and his belongings, living things and non-living things. sandcrete block happened to be the commonly used building material for construction in dominating over $90 \%$ of physical infrastructures in Nigeria, (baiden and tuuli, 2004). the major challenge is that block producers have not been working to meet up with prescribed standard or have resorted to use substandard materials for profit making.

Revised Manuscript Received on April 02, 2020.

* Correspondence Author

Govind Singh Chauhan*, Assistant Professor, Civil Engineering Department, Mewar University, Chittorgarh, India govindsingh.singh865@gmail.com

Mahmoud Murtala Farouk, Lecturer II, Civil Engineering Department, Kano University of Science and Technology, Wudil, kano Nigeria mahmoudmurtala@ganil.com

Auwal Alhassan Musa, Post Graduate Scholar Civil Engineering Department, Mewar University, Chittorgarh, India auwalalhassanmusa@gmail.com

Lasmar Garba, Post Graduate Scholar Civil Engineering Department, Mewar University, Chittorgarh, India garbalasmar@gmail.com

(C) The Authors. Published by Blue Eyes Intelligence Engineering and Sciences Publication (BEIESP). This is an open access article under the CC BY-NC-ND license (http://creativecommons.org/licenses/by-nc-nd/4.0/)
Studies conducted by (Onwukaet.al, 2013) revealed that major challenge is that Sandcrete block producers have neglected standard by using substandard materials primarily to optimized their gain. Manual or machinery method adopted in the manufacturing process and Engineering properties are main factors that determine the quality of Sandcrete blocks for both load bearing and non-load bearing structures (Rahman, 2012). (Omopariola., 2014) viewed that commercial block producers have violated the use any relevant code or specifications relating to block production and properties. He further stated that standard process of sandcrete block production and quality control is not ensured which its consequence for the production of low quality sandcrete blocks. (Omoregie., 2012) confirmed it by stating that the production of low-quality blocks may have led to increase in collapsed buildings in recent time.

According to (Abdullahi, 2005) the variability of materials properties, methods of manufacturing have a role to play in predicting the strength properties of sandcrete blocks.

The quality of sand has a great influence on the quality of block as it constitutes between $75-90 \%$ of blocks by weights (Anosike and Oyebade, 2012). The quality of sand is influenced by its source grading and storage condition.

The most terrifying challenges identified in Nigeria during the recent decades is provision of safe, durable and comfortable shelter. In order to be able to control or to minimize the occurrence of these menaces, it is necessary to have knowledge about properties and general quality of the sandcrete blocks. Therefore, this research aims at assessing the quality of sandcrete blocks produced in Kano Municipal Local Govt. Kano.

\section{STUDY AREA}

Kano municipal is a local government located within Kano state metropolis and its known as capital of the state which lies at longitude of 11 o $57^{\prime} 07^{\prime}$ ' $\mathrm{N}$ and latitude of 8032'25''E with an approximate area of $17.00 \mathrm{~km} 2$ and density of $24400 / \mathrm{km}$ (Wikipedia.com) and with a population of 365,525 (NPC, 2006).

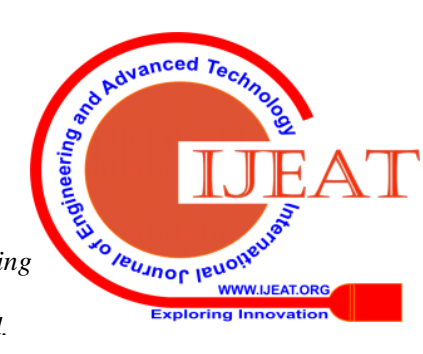



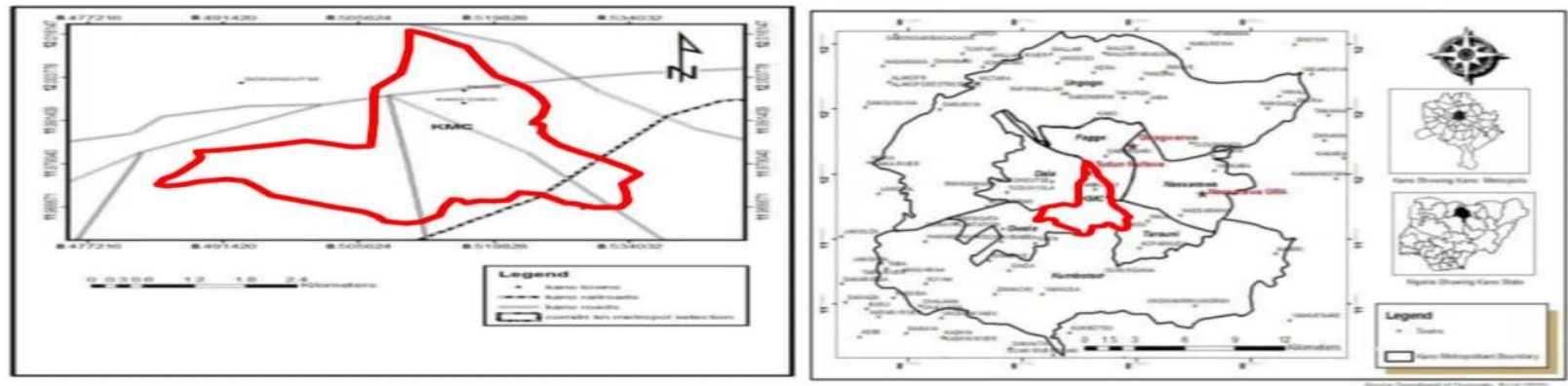

Figure 1.1: The Study Area (Wikipedia)

\section{RESEARCH METHODOLOGY}

Field survey and laboratory experiments were adopted in this research. The field survey of sandcrete blocks industries within Kano municipal local government Kano state was carried out to identify the location of all manufacturing and selling points of sandcrete blocks. Fourteen (14) block industries were visited and interviewed, some observations made during the industrial survey include; batching and mix ratios, method of mixing, addition of water and curing. Six (6) samples each with dimensions 450mm x150mm x225 mm (6 inches) were obtained. the samples of sandcrete blocks were subjected the compressive strength tests and water absorption test. are the two major characteristic requirements the NIS specified for testing and verifying the quality of sandcrete block apart from the appearance and Dimension (NIS87:2007).

The tests carried out on the sandcrete blocks were;

i. Water Absorption Capacity test

ii. Compressive Strength test

\section{1: Water Absorption Capacity Test}

This test was conducted in accordance with specification given in the (NIS87:2007). for the production of sandcrete blocks.

the result was computed using the relationship below;

Water Absorption Capacity $(\%)=$

$\frac{M_{2}-M_{1}}{M_{1}} \times 100$.

Where: $\left(M_{1}\right)=$ Weight of dry block before immersion and $\left(M_{2}\right)=$ Weight of wet block after immersion.

The average of the results obtained was regarded as the water absorption of the block and shall not exceed $12 \%$ (NIS87:2007).

\section{2: Compressive Strength Test}

This test was conducted in accordance with specification given in the (NIS87:2000) for the production of sandcrete blocks. The compressive strength of the sandcrete blocks was determined through crushing of the sandcrete block, this was carried out on all blocks.

the result was computed using the relationship below the expression.

Compressive Strength $\left(\mathrm{N} / \mathrm{mm}^{2}\right)$

\section{$=\frac{\text { maximumloadatfailure }(\mathrm{N})}{\text { crosssectionaarea }\left(\mathrm{mm}^{2}\right)} \times 100$}

The average results obtained was taken as the crushing strength of the blocks and shall not be less than $3.45 \mathrm{~N} / \mathrm{mm} 2$ for load bearing hollow sandcrete blocks and $2.5 \mathrm{~N} / \mathrm{mm} 2$ for non-load bearing hollow sandcrete blocks produced by machine (NIS87:2007);

\section{RESULT}

Visitations conducted were made to the selected block industries within the study area and their respective names were represented by nomenclatures as follows; A, to $\mathrm{N}$ alphabetically. the method they usually employed is batching by weight (1:3:12), (cement: dust: sand) and this usually produce 45-50 no of blocks out of one bag of Portland cement, due to inadequate mixing machinery and less orders for blocks, the manual method of mixing ingredients is usually adopted. The curing age of the blocks usually varied from two times to three times in a day within three consecutive days to attend required strength for construction. 4.2 Water Absorption Capacity of Sandcrete Block Result.

The table below shows the water absorption capacity for all samples collected from various blocks factories, with value ranging from $18.10 \%$ to $14.67 \%$ As such the pore spaces between the particles are large and absorb appreciable water, this is because the sand particles are smaller and contain high amount of silt that absorb much water which affect the strength properties of sandcrete block

Table 2.0: Mean Compressive Strength of Sandcrete Block of the Factories.

\begin{tabular}{|c|c|c|c|c|c|c|c|c|c|c|c|c|c|c|}
\hline $\begin{array}{c}\text { Block } \\
\text { Factories }\end{array}$ & $A$ & B & $C$ & D & $E$ & $F$ & G & $\mathrm{H}$ & I & $\mathrm{J}$ & K & $\mathrm{L}$ & $\mathrm{M}$ & $\mathrm{N}$ \\
\hline $\begin{array}{c}\text { Compress } \\
\text { ive } \\
\text { Strength } \\
\left(\mathrm{N} / \mathrm{Mm}^{2}\right)\end{array}$ & $\begin{array}{c}0.48 \\
84\end{array}$ & $\begin{array}{c}0.34 \\
79\end{array}$ & $\begin{array}{c}0.47 \\
62\end{array}$ & $\begin{array}{c}0.36 \\
83\end{array}$ & $\begin{array}{c}0.44 \\
20\end{array}$ & $\begin{array}{c}0.44 \\
20\end{array}$ & $\begin{array}{c}0.47 \\
62\end{array}$ & $\begin{array}{c}0.36 \\
83\end{array}$ & $\begin{array}{c}0.47 \\
42\end{array}$ & $\begin{array}{c}0.43 \\
36\end{array}$ & $\begin{array}{c}0.44 \\
97\end{array}$ & $\begin{array}{c}0.34 \\
80\end{array}$ & $\begin{array}{c}0.28 \\
69\end{array}$ & $\begin{array}{c}0.35 \\
21\end{array}$ \\
\hline
\end{tabular}

Published By:

Blue Eyes Intelligence Engineering

\& Sciences Publication

(C) Cobvriaht: All riahts reserved.

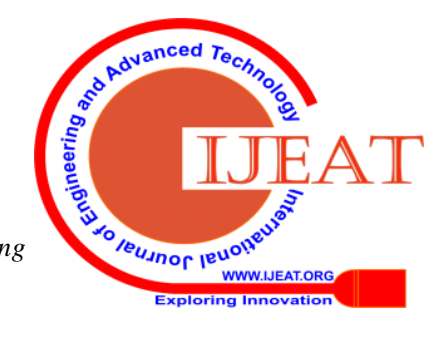




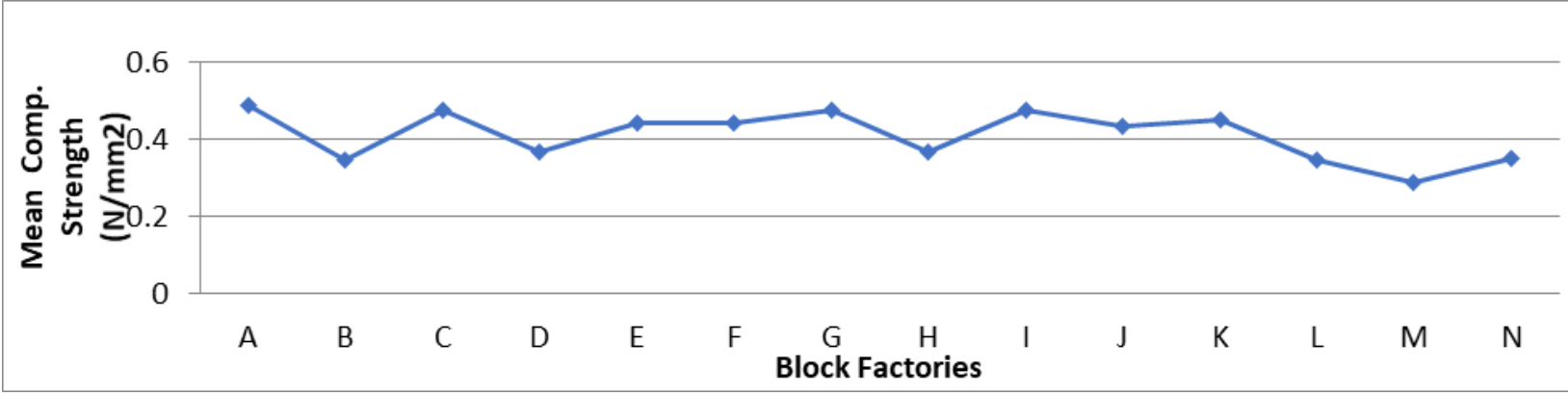

Fig 3.0: Mean Compressive Strength of Sandcrete Block

The test result in figure 3.0 above shows that the strength of block samples is dependent on the weight of the blocks; because some blocks that have high weight and do not have high compressive strength, while some blocks with low density have high compressive strength. This is because they are not in line with the standard.

\section{CONCLUSIONS}

following conclusions were drawn from the research work carried out:

The water absorption capacity test for all the blocks revealed that almost all the sandcrete blocks were above the maximum specified $12 \%$ as stated by the (NIS87: 2007) Water absorption with values ranging from $14.67 \%$ to $18.10 \%$ with block having an average value of $16.02 \%$ water absorption capacity. As such the pore spaces between the particles are large and absorb appreciable water, this is because the sand particles are smaller and contain high amount of silt that absorb much water which affect the strength properties of sandcrete block.

The strength for all the blocks tested revealed that almost all the sandcrete blocks were below the minimum specified value of $2.8 \mathrm{~N} / \mathrm{mm}^{2}$, as stated by (NIS $87: 2000$ ). The compressive strength of individual block tested ranges from $0.2869 \mathrm{~N} / \mathrm{mm}^{2}$ to $0.4884 \mathrm{~N} / \mathrm{mm}^{2}$ while the average strength of the fourteen factories was $0.432 \mathrm{~N} / \mathrm{mm}^{2}$.

The compressive strength of sandcrete blocks was very low and also below the Standard recommended by Nigeria Industrial Standard (NIS87:2000) of values ranging from $2.5 \mathrm{~N} / \mathrm{mm}^{2}$ to $3.45 \mathrm{~N} / \mathrm{mm}^{2}$.

Finally, the manufacturers ignored all the recommended tests on the sandcrete block either before or at the end of production. the low compressive strength is due to low mix ratio, inadequate curing, the low compaction causes low value of compressive strength of sandcrete block.

\section{RECOMMENDATIONS}

It is recommended that the manufacturers should improve on their material selection and curing processes by constantly referring to NIS provision in order to produce sandcrete blocks of high quality.

the standard organization of Nigeria (SON) in conjunction with relevant agencies should jointly control and enforce laws that must be strictly adhere with in the production process of sandcrete block in Kano municipal local government. Kano state, Nigeria.

\section{ACKNOWLEDGMENT}

We wish to appreciate the effort of our family for encouraging and supporting this research tirelessly. Also, special thank to our friends Tajuddeen Mustapha, Zakariya Ibrahim Musa and Shehu Usman Muhammad for encouraging us in this research work.

\section{REFERENCES}

1 Abdullahi A. (2005). "Compressive Strength of Sandcrete Blocks in Bosso and Shiroro Areas of Minna, Nigeria”. AUJ.T.9 (2): 126-131.

2 Anosike B. and Oyebade H. (2012). "Sandcrete Blocks and Quality Management in Nigeria Building Industry”. Journal of Engineering, Project, and Production Management, 2 (1), 37-46.

3 Baiden, B. K. and Tuuli, M. (2004). "Impact of quality control practices in sandcrete Blocks production", Journal of Architectural Engineering, 10 (2), 55-60.

4 D. O. Onwuka, N. N Osadebe and C. E. Okere (2013), "Structural Characteristics of Sandcrete Blocks Produced in South east Nigeria". (Journal of Innovative Research in Engineering and Sciences,4 (3), pp.483-490

5 National Population Commissions (NPC, 2006)

6 NIS 87:2007. Nigerian Industrial Standard: Standard for Sandcrete Blocks.

7 Omopariola, S. S. (2014) "An Appraisal of the Quality Control Practices in Sandcrete Blocks Production in Yewa South Area of Ogun State, Nigeria”. "American Journal of Engineering Research (AJER) Volume-03, Issue-04, pp-01-07".

8 Omoregie, A. (2012): "Impact of vibration time on compressive strength of Hardened Sandcrete blocks". Buildings2pp153-172

9 Rahman, M.A. (2012). "Use of Rice Husk Ash in Sandcrete Blocks for Masonry Units:" Materials and Structures, 20(5),361-3

\section{AUTHORS PROFILE}

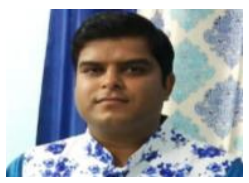

Govind Singh Chauhan: Assistant Professor, Civil Engineering Department, Mewar University, Chittorgarh, govindsingh.singh865@gmail.com

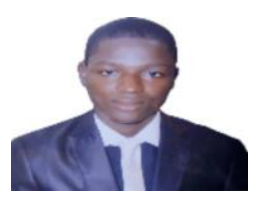

Auwal Alhassan Musa: Post Graduate Scholar, Civil Engineering Department, Mewar University, Chittorgarh, India

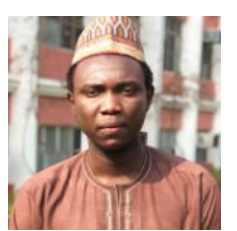

Lasmar Garba: Post Graduate Scholar Civil Engineering Department, Mewar University, Chittorgarh, India garbalasmar@gmail.com

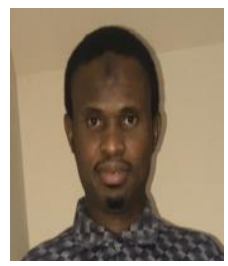

Mahmoud Murtala Farouk: Lecturer II,

Civil Engineering Department,

Kano University of Science and Technology,

Wudil, kano Nigeria mahmoudmurtala@ganil.com

Published By:

Blue Eyes Intelligence Engineering \& Sciences Publication

(C) Cobvriaht: All riahts reserved.

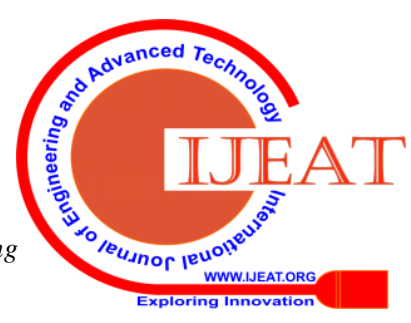

